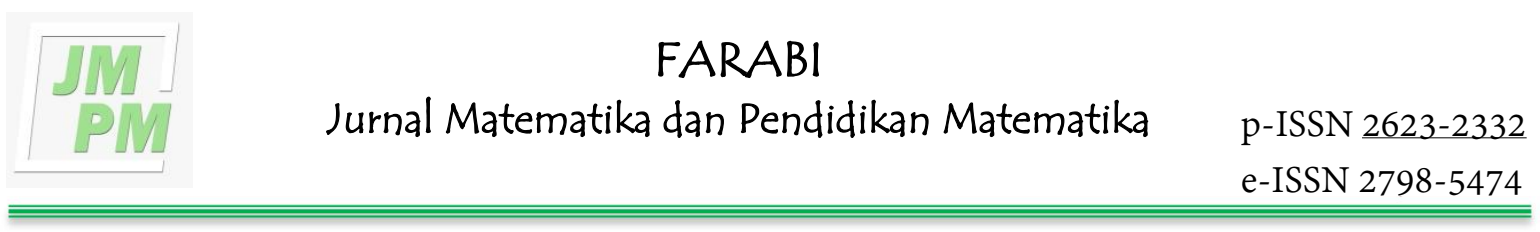

\title{
Pengaruh Model Pembelajaran Kontekstual Terhadap Kemampuan Pemecahan Masalah
}

\author{
Khoiruddin Matondang ${ }^{1}$, Ade Rahman Matondang ${ }^{2}$, Risna Mira Bella Saragih ${ }^{3}$, \\ Israq Maharani ${ }^{4}$ \\ ${ }^{1,3,4}$ Prodi Pendidikan Matematika, FKIP, Universitas Al Washliyah, Medan-Indonesia \\ ${ }^{2}$ Pendidikan Islam Anak Usia Dini, FKIP, Universitas Al Washliyah, Medan-Indonesia \\ Email: khoir86matondang@gmail.com
}

\begin{abstract}
ABSTRAK
Tujuan dalam penelitian ini adalah untuk mengetahui pengaruh model pembelajaran kontekstual terhadap kemampuan pemecahan masalah dan motivasi belajar siswa. Penelitian ini merupakan penelitian kuasi eksperimen. Populasi penelitian ini adalah seluruh siswa/I kelas VII SMP Yaspi Labuhan Deli. Instrument yang digunakan tes pemecahan masalah dan angket motivasi belajar siswa. Tes dan angket tersebut dinyatakan telah memenuhi syarat validitas dan reliabilitas sebesar 0,82 dan 0,76 . Analisis data dilakukan dengan uji $t$ dan skala likert. Hasil dari penelitian ini adalah (1) terdapat pengaruh model pembelajaran kontekstual terhadap kemampuan pemecahan masalah siswa (2) terdapat pengaruh model pembelajaran kontekstual terhadap motivasi belajar siswa.
\end{abstract}

Kata kunci : kontekstual, pemecahan masalah siswa.

\section{ABSTRACT}

The purpose of this study was to determine the effect of the contextual learning model on problem solving abilities and student motivation. This research is a quasi-experimental research. The population of this study were all students of class VII SMP Yaspi Labuhan Deli. The instruments used are problem solving tests and student motivation questionnaires. The tests and questionnaires were declared to have met the validity and reliability requirements of 0.82 and 0.76 . Data analysis was done by t test and Likert scale. The results of this study are (1) there is an effect of contextual learning model on students' problem solving ability (2) there is an influence of contextual learning model on students' learning motivation.

Keywords: contextual, student problem solving.

\section{A. Pendahuluan}

Dalam penyelesaian pada pelajaran matematika siswa sering tidak menjabarkan jawaban yang diketahuinya dari soal, maka diperlukan strategi pembelajaran pemecahan masalah. Menurut Wena (2011: 53) Kemampuan pemecahan masalah sangat penting artinya bagi siswa dan masa depannya. Para ahli pembelajaran sependapat bahwa kemampuan pemecahan masalah dalam batas-batas tertentu, dapat dibentuk dalam melalui bidang studi dan ilmu yang diajarkan. Menurut Wena (2011:52) pemecahan masalah dipandang sebagai suatu proses untuk menemukan kombinasi dari sejumlah aturan yang dapat diterapkan. Pemecahan masalah merupakan proses untuk mendapatkan suatu kombinasi perangkat aturan pada tingkat yang lebih tinggi. Apabila seseorang telah mendapatkan suatu kombinasi perangkat aturan yang terbukti dapat dioperasi kan sesuai dengan situasi yang sedang dihadapi maka ia tidak saja dapat memecahkan masalah, melainkan juga telah berhasil menemukan sesuatu yang baru. Sesuatu yang dimaksud adalah perangkat

Copyright (c) 2021 FARABI: Jurnal Matematika dan Pendidikan Matematika

Volume 4 Nomor 1, Juni 2021, pp. $69-73$ 
prosedur atau strategi yang memungkinkan seseorang dapat meningkatkan kemandirian dalam berpikir. Solso (dalam Made Wena 2011:56) mengemukakan enam tahap dalam pemecahan masalah yaitu 1) Identifikasi Permasalahan; 2) Representasi; 3) Perencanaan pemecahan; 4) menerapkan perencanaan; 5) menilai perencanaan; 6) menilai hasil pemecahan.

Hasil observasi yang dilakukan di SMP Yaspi Labuhan Deli kelas VII kepada guru matematika yaitu Suryani S.Pd dan siswa, ditemukan siswa masih banyak yang kurang memahami persoalan pada materi dengan menggunakan pemecahan masalah matematika. Permasalahan ini mengakibatkan prestasi siswa semakin rendah dan mengalami kemerosotan nilai. Hal ini menunjukkan bahwa terdapat masalah yang terjadi dalam proses pembelajaran.

Model pembelajaran yang kurang efektif mengakibatkan siswa tidak termotivasi belajar, Menurut (Agustin, 2011:46) model pembelajaran yang kurang efektif cenderung akan mengurangi motivasi dan pemicu sulitnya anak memahami materi matematika. Menurut (Trianto, 2011) siswa menghadapi kesulitan memahami konsep akademik seperti matematika saat mereka diajar dengan metode konvensional, padahal mereka sangat perlu untuk memahami konsep-konsep saat mereka berhubungan dengan dunia kerja, model pembelajaran yang digunakan oleh guru harusnya menggunakan model pembelajaran kontekstual yang membantu guru untuk mangaitkan konten mata pelajaran dengan situasi dunia nyata dan memotivasi siswa membuat hubungan antara pengetahuan dan penerapannya dalam kehidupan mereka sebagai anggota keluarga. Dari observasi pada siswa, peneliti memberikan soal pemecahan masalah dan dari 43 siswa terdapat hanya 18 siswa (41\%) yang melakukan penyelesaian soal dengan menggunakan pemecahan masalah, adapun berikut soal dan jawaban dari salah satu siswa yang belum benar dalam menyelesaikan pemecahan masalah.

\section{B. Metode Penelitian}

Penelitian ini akan dilaksanakan di SMP Yaspi Labuhan Deli Jl.Yos Sudarso KM.06. Penelitian ini dikategorikan ke dalam penelitian eksperimen semu (quasi experiment). Rancangan penelitian yang digunakan dalam penelitian ini adalah Pretes Posttest Control Group Design. Rancangan penelitiannya disajikan dengan skema seperti berikut:

Tabel 1 Rancangan Penelitian

\begin{tabular}{|l|l|l|l|}
\hline Kelas & Pretes & Perlakuan & Postest \\
\hline Eksperimen & $\mathrm{O}$ & $\mathrm{X}$ & $\mathrm{O}$ \\
\hline Kontrol & $\mathrm{O}$ & & $\mathrm{O}$ \\
\hline
\end{tabular}

Tabel 2 Analisis Reliabilitas Soal

\begin{tabular}{|c|c|c|c|c|}
\hline & Soal 1 & Soal 2 & Soal 3 & Soal 4 \\
\hline Varians butir soal & 1,254 & 6,377 & 1,403 & 1,364 \\
\hline Jumlah varians butir soal & \multicolumn{4}{|c|}{7,582} \\
\hline Varians total & \multicolumn{4}{|c|}{19,935} \\
\hline Koefisien reliabilitas & \multicolumn{4}{|c|}{0,82} \\
\hline Interpretasi & \multicolumn{4}{|c|}{ Sangat Tinggi } \\
\hline
\end{tabular}

Tabel 3 Hasil perhitungan tingkat kesukaran

\begin{tabular}{|l|c|c|c|c|}
\hline & Butir soal 1 & Butir soal 2 & Butir soal 3 & Butir soal 4 \\
\hline Indeks & 0,67 & 0,54 & 0,82 & 0,83 \\
\hline Interpretasi & Sedang & Sedang & mudah & mudah \\
\hline
\end{tabular}

Teknik yang digunakan untuk menghitung daya pembeda bagi tes bentuk uraian adalah dengan menghitung batas atas dan batas bawah dari jumlah siswa. Hasil analisis daya 
pembeda kemampuan pemecahan masalah dapat dilihat dari tabel dibawah ini.

Tabel 4. Hasil perhitungan daya pembeda pada pemecahan masalah

\begin{tabular}{|l|c|c|c|c|}
\hline & Butir soal 1 & Butir soal 2 & Butir soal 3 & Butir soal 4 \\
\hline Skor maks ideal & 12 & 12 & 12 & 12 \\
\hline Jumlah skor kelompok atas & 137 & 114 & 150 & 172 \\
\hline $\begin{array}{l}\text { Jumlah skor kelompok } \\
\text { bawah }\end{array}$ & 125 & 101 & 139 & 151 \\
\hline Indeks & 0,019 & 0,032 & 0,009 & 0,057 \\
\hline Interpretasi & Cukup & Cukup & cukup & baik \\
\hline
\end{tabular}

\section{Hasil dan Pembahasan}

Data pretest kelas eksperimen berdistribusi normal. Data pretest didapat $\mathrm{L}_{\text {hitung }}=0,0898$ dan $\mathrm{L}_{\text {tabel }} 0,1591$. L L hitung $<$ $\mathrm{L}_{\text {tabel }}$ atau $0,0898<0,1591$ maka data pretest berdistribusi normal. Data postest kelas eksperiment juga berdistribusi normal. Data postest didapat $\mathrm{L}_{\text {hitung }}=0,1328$ dan $\mathrm{L}_{\text {tabel }}=$ 0,1591. L $\mathrm{L}_{\text {hitung }}<\mathrm{L}_{\text {tabel }}$ atau $0,1328<0,1591$ maka data postest berdistribusi normal.

Dari pretest kelas kontrol berdistribusi normal. Dari data pretest dengan $\mathrm{L}_{\text {hitung }}=0,0898$ dan $\mathrm{L}_{\text {tabel }} 0,1591$. $\mathrm{L}_{\text {hitung }}<\mathrm{L}_{\text {tabel }}$ atau $0,0898<$ 0,1591 maka data pretest berdistribusi normal. Dari postest kelas kontrol juga berdistribusi normal. $\mathrm{L}_{\text {hitung }}=0,0310$ dan $\mathrm{L}_{\text {tabel }}=0,035$. $\mathrm{L}_{\text {hitung }}$ $<\mathrm{L}_{\text {tabel }}$ atau $0,0310<0,035$ maka data postest berdistribusi normal.

Untuk menguji homogenitas data kemampuan pemecahan masalah siswa digunakan uji Statistik (t). untuk kriteria pengujian data kedua sampel adalah homogen jika $t_{\text {hitung }}<t_{\text {tabel }}$ pada taraf $\alpha=0,05$. Diperoleh data pretest dan postest seperti tabel berikut.

Tabel 5. Uji homogen Pretest dan Postest

\begin{tabular}{|c|c|c|}
\hline Pretest & Posttest & $\mathbf{t}_{\text {tabel }}$ \\
\hline 1,80 & 1,89 & \\
Dk pembilang=30, & $\begin{array}{c}\text { Dk pembilang } \\
=30, \\
\text { Dk penyebut }=24\end{array}$ & \multirow{2}{*}{1,94} \\
& $\begin{array}{c}\text { Dk penyebut }= \\
24\end{array}$ & \\
& $\mathrm{n}_{1}=31, \mathrm{n}_{2}=25$ \\
$\mathrm{n}_{1}=31, \mathrm{n}_{2}=25$ & $1,89<1,94$ & \\
\hline $1,80<1,94$ & Homogen & \\
Homogen & \\
\hline
\end{tabular}

Dari tabel diatas data pretest diperoleh $t_{\text {hitung }}<t_{\text {tabel }}(1,80<1,94)$. Sehingga sampel dalam penelitian ini adalah homogen. Untuk data postest diperoleh $t_{\text {hitung }}<t_{\text {tabel }}(1,89<1,94)$, sehingga sampel dalam penelitian ini adalah homogen.

Penelitian ini diawali dengan pemberian soal pretest di kelas eksperimen dan kontrol. Adapun nilai rata-rata pretest dan kedua kelas dapat dilihat pada tabel berikut.

Tabel 6. Nilai rata-rata pretest siswa kelas eksperimen dan kontrol

\begin{tabular}{|l|c|}
\hline \multicolumn{1}{|c|}{ Kelas } & Nilai rata-rata pretest \\
\hline Eksperimen & 60,69 \\
\hline Kontrol & 61,08 \\
\hline
\end{tabular}

Dari tabel diatas dapat dijelaskan bahwa terdapat nilai rata-rata pretest siswa kelas eksperimen adalah 60,69 dan rata-rata nilai postest kelas kontrol adalah 61,08 . Dari nilai ratarata kedua kelas dapat dilihat bahwa nilai pretest kelas eksperimen lebih rendah dibandingkan kelas kontrol atau 60,69 <61,08. Berikut dapat disajikan diagram nilai pretest siswa kelas eksperimen dan kelas kontrol.

Setelah diberikan perlakuan model pembelajaran kepada kedua kelas, untuk mengetahui peningkatan kemampuan pemecahan masalah siswa diberikan soal postest kepada kedua kelas yaitu kelas eksperimen dan kelas kontrol. Kemudian diperoleh nilai rata-rata postest siswa seperti tabel berikut :

Tabel 7. Nilai rata-rata postest siswa kelas eksperimen dan kontrol

\begin{tabular}{|l|c|}
\hline \multicolumn{1}{|c|}{ Kelas } & Nilai rata-rata postest \\
\hline Eksperimen & 82,87 \\
\hline Kontrol & 59 \\
\hline
\end{tabular}

Dari tabel diatas dapat dijelaskan bahwa niali rata-rata dikelas eksperimen sebesar 82,87 dan nilai rata-rata dikelas kontrol sebesar 59 . Terdapat perbandingan nilai rata-rata pretest dan 
postest dikelas eksperimen setelah diberi perlakuan model pembelajaran kontekstual yaitu 82,87 dan 60,69 . Berikut disajikan diagram nilai rata-rata postest siswa kelas eksperimen dan kontrol.

Untuk menguji hipotesis digunakan rumus uji statistik t. pada perhitungan diperoleh varians gabungan dari dua kelompok sebesar 0,362 dan uji $\mathrm{t}$ sebesar 2,460. $\mathrm{T}_{\text {tabel }}$ dicari dengan menggunakan interpolasi $\alpha=0,05$ dan $-t_{1}-\frac{1}{2} a<$ $\mathrm{t}<\mathrm{t}_{1}-\frac{1}{2}$ a diperoleh $\mathrm{t}_{\text {tabel }}$ sebesar 2,006, dengan membandingkan nilai $t_{\text {hitung }}$ dengan nilai $t_{\text {tabel }}$ jika diperoleh $t_{\text {hitung }}>t_{\text {tabel }}$ maka hipotesis Ha diterima namun jika $t_{\text {hitung }}<t_{\text {tabel }}$ maka Ha ditolak. Dari perhitungan tersebut dapat dijelaskan bahwa $t_{\text {tabel }}>\mathrm{t}_{\text {hitung }}$ yaitu $2,460>2,006$ maka $\mathrm{Ha}$ diterima. Sehingga dapat disimpulkan bahwa model pembelajaran kontekstual dapat mempengaruhi kemampuan pemecahan masalah. Adapun yang mempengaruhi pemecahan masalah pada model pembelajaran kontekstual adalah dalam proses belajar siswa aktif berdiskusi, sifat keingintahuan siswa berkembang pada proses belajar dengan media pembelajaran yang berkaitan dengan kehidupan sehari-hari.

Hasil penelitian yang telah dijelaskan sebelumnya menunjukkan bahwa peningkatan kemampuan pemecahan masalah siswa dengan pembelajaran kontekstual lebih baik dibandingkan dengan pembelajaran konvensional. Hasil temuan ini diperkuat temuan Primayana (2019) yang dalam penelitiannya menemukan bahwa ) terdapat perbedaan hasil

belajar IPA antara siswa yang mengikuti pembelajaran kontekstual berbasis lingkungan dan siswa yang mengikuti model pembelajaran konvensional pada siswa minat outdoor rendah . Begitu pula penemuan putri (2019) penerapan model pembelajaran kontekstual berpengaruh cukup tinggi dalam meningkatkan hasil belajar siswa. dalam penelitiannya kemampuan pemecahan masalah matematika siswa yang diajar dengan pembelajaran kontekstual lebih baik dibandingkan siswa yang diajar dengan pendekatan traditional.

Keunggulan pembelajaran kontekstual dapat dilihat melalui perbedaan pandangan terhadap karakteristik pendekatan, antara lain bahan ajar, selama mengajar menggunakan pembelajaran kontekstual Masalah kontekstual dapat berupa masalah yang berkaitan dengan kehidupan sehari-hari. Hal tesebut sesuai dengan pendapat Zakiah (2019) yang menyatakan adanya masalah kontekstual yang dapat mengaitkan pengalaman kehidupan sehari-hari dan budaya siswa dalam membangun pengetahuan matematika formal.

Menurut Arafani (2019) Siswa harus dipandang sebagai human being yang memiliki seperangkat pengetahuan dan pengalaman yang diperoleh melalui interaksi dengan lingkungannya. Kegiatan yang masyarakat belajar menjadi karakteristik pembelajaran kontekstual. Kelompok siswa dibentuk dalam kelompok heterogen yang terdiri 4-6 orang menjadikan siswa saling menyelesaikan masalah.

Menurut Setiawan (2019) pembelajaran kontekstual menjadi salah satu alternatif yang ditawarkan untuk memperbaiki proses pembelajaran yang selama ini berpusat pada guru. Anggraini (2017) juga menyatakan bahwa karakteristik pembelajaran kontekstual menjadi jawaban atas karakteristik pembelajaran. Apriani (2017) juga menyatakan Peran guru dalam pembelajaran kontekstual harus memberikan kesempatan kepada siswa untuk secara aktif melakukan aktivitas pembelajaran. Sebaliknya dalam pembelajaran konvensional guru memegang peran utama sebagai sumber belajar, menjelaskan materi dan contoh-contoh, membahas secara bersama dan memberikan latihan berkaitan dengan materi yang telah dijelaskan.

\section{Kesimpulan dan Saran}

Berdasarkan hasil dan pembahasan selama pelaksanaan pembelajaran dengan pembelajaran kontekstual, diperoleh kesimpulan yang merupakan jawaban atas pertanyaan yang diajukan dalam rumusan masalah. Kesimpulan tersebut adalah Berdasarkan hasil pembahasan pada bab IV diperoleh beberapa kesimpulan yang merupakan jawaban atas pertanyaan-pertanyaan yang diajukan dalam rumusan masalah, kesimpulankesimpulan tersebut yaitu terdapat pengaruh model pembelajaran kontekstual terhadap kemampuan pemecahan masalah siswa dengan membandingkan nilai posttest kelas eksperimen dan kelas kontrol dimana $t_{\text {hitung }}$ dan $t_{\text {tabel }}$ diperoleh $t_{\text {hitung }} 2,460>t_{\text {tabel }} 2,006$.

\section{E. Daftar Pustaka}

Agustin, M.2011. Permasalahan Belajar dan Inovasi Pembelajaran .Bandung. PT.Refika Aditama. 
Anggraini, Dewi. 2019. Penerapan pembelajaran kontekstual pada Pendidikan anak usia dini. Jurnal Yaa Bunayya. https://jurnal.umj.ac.id/index.php/YaaBu nayya/article/view/1722.

Apriani, dkk. 2017. Penerapan Contextual Teaching and Learning (CTL)untuk meningkatkan keterampilan proses sains pada Materi Perubahan Sifat Benda. https://ejournal.upi.edu/index.php/penail miah/article/view/10675.

Primayana. 2019. Pengaruh Model Pembelajaran Kontekstual Berbasis Lingkungan terhadap Hasil Belajar IPA Ditinjau dari Minat Outdoor pada Siswa KELAS IV . https://ejournal-

pasca.undiksha.ac.id/index.php/jurnal_ip a/article/view/2905.

Putri, dkk. 2019. Pengaruh Penerapan Model Pembelajaran Kontekstual dalam Pembelajaran Fisika terhadap Hasil Belajar Siswa pada Materi Energi Terbarukan. Jurnal Ilmiah Multi Sciences, Vol. 11 No. 2, Halaman: 87- 93, Juli 2019.

https://journal.stkipnurulhuda.ac.id/index. $\mathrm{php} / \mathrm{JTI} / \mathrm{article} / \mathrm{view} / 474$.

Rukajat. 2019. Pembelajaran Contextual Teaching and Learning untuk Meningkatkan Mutu Hasil Pembelajaran. Pioner Jurnal Pendidikan. https://jurnal.arraniry.ac.id/index.php/Pionir/article/view 14589.

Setiawan, Panji. Sudana. 2019. Penerapan Model Pembelajaran Kontekstual untuk Meningkatkan Hasil Belajar Matematika Jurnal Ilmiah Pendidikan Profesi Guru Vol. 2 No. 3, Oktober 2019. P-ISSN : 2621-5713, E-ISSN : 2621-5705

Sugiyono. 2011. Metode Penelitian Pendidikan pendekatan Kuantitatif, Kualitatif, dan $R$ $\& D$. Bandung. Alfabeta.

Trianto. 2011. Mendesain Model Pembelajaran Inovatif-Progresif. Jakarta. Kencana Prenada Media Group.
Wena,M. 2011. Strategi Pembelajaran Inovatif Kontemporer. Jakarta. PT.Bumi Aksara.

Zakiah, dkk. 2019. Implementasi Pendekatan Kontekstual pada Model Pembelajaran Berbasis Masalah berdasarkan Langkah-Langkah Polya. Jurnal Teorema: Teori dan Riset Matematika, 4(2), 111-120, September 2019. https://jurnal.unigal.ac.id/index.php/teore $\underline{\mathrm{ma} / \text { article/view/2706 }}$ 